\title{
Additive manufacturing and mechanical characterization of high density fully
}

\author{
stabilized zirconia \\ Amir Ghazanfari *,a ${ }^{*}$ Wenbin Li ${ }^{\text {a }}$, Ming C. Leu ${ }^{\text {a }}$ \\ Jeremy L. Watts ${ }^{\text {b }}$, Gregory E. Hilmas ${ }^{\text {b }}$ \\ ${ }^{a}$ Department of Mechanical and Aerospace Engineering, Missouri University of Science and \\ Technology, Rolla, MO, 65409, USA \\ ${ }^{\mathbf{b}}$ Department of Materials Science and Engineering, Missouri University of Science and \\ Technology, Rolla, MO, 65409, USA
}

Mechanical properties of additively manufactured $8 \mathrm{~mol} \%$ yttria-stabilized zirconia (8YSZ) parts were extensively studied for the first time. A novel freeform extrusion fabrication process, called Ceramic On-Demand Extrusion (CODE), was employed to deposit an aqueous viscous suspension ( $\sim 50 \mathrm{vol} \%$ solids loading) of fully stabilized zirconia powder in a layer-by-layer fashion. Each layer was exposed to infrared radiation after deposition to attain partial solidification due to drying. Before exposure, the layer was surrounded by oil to preclude nonuniform evaporation, which could cause warpage and crack formation. After the fabrication process was completed, the parts were humid-dried in an environmental chamber and densified by sintering under atmospheric pressure. Standard test methods were employed to examine the properties of sintered parts including density, Vickers hardness, fracture toughness, Young's modulus, and flexural strength. Microstructural evaluation was also performed to observe the

* Corresponding author (amir.ghazanfari@mst.edu) 
microstructural morphology and measure grain size. The results indicate that the properties of 8YSZ parts produced by the CODE process match those obtained by conventional fabrication techniques.

Keywords: Zirconium dioxide; Yttria; 3D printing; Mechanical properties.

\section{Introduction}

Fully stabilized cubic zirconia has several desirable properties including high ionic conductivity, thermal and chemical stability, and mechanical strength [1]. The combination of these properties makes this material attractive for use as electrolytes in Solid Oxide Fuel Cells (SOFCs), oxygen sensors, oxygen separators and electrochemical reactors [2]. A geometrically complex design for an electrolyte can increase the efficiency of an SOFC by increasing the surface area between the cathode and the electrolyte [3]. It can also increase the load-bearing capacity, which is a critical factor for fuel cell stacks [4]. Several researchers have designed and fabricated structured electrolytes or support structures for SOFCs using various manufacturing techniques, as explained below.

Beeaff and Hilmas [5] used an extrusion technique to fabricate a honeycomb of zirconia laminated to a planar electrolyte in order to increase the strength of the SOFC. Ding and Liu [6] fabricated cone-shaped tubular segmented-in-series SOFC stacks using slip casting and deposited yttria-stabilized zirconia films onto the anode tubes by dip coating. Their results showed good thermo-mechanical properties and enhanced performance for the fuel cell. Yamaguchi et al. [7] fabricated a cathode-supported honeycomb SOFC via extrusion of a monolith and used a slurry injection method for the channel surface coating in order to increase the volumetric power density. Ruiz-Morales et al. [8] fabricated a honeycomb electrolyte to reduce the electrolyte thickness and increase the structure's mechanical strength. Their results showed an improvement 
in volumetric power density and material usage. Rajeswari et al. [9] made structured electrolytes by thermally induced gelation of an aqueous zirconia slurry containing methylcellulose using microwave irradiation. Celik et al. [10] produced tapes of $3 \mathrm{~mol} \%$ and $8 \mathrm{~mol} \%$ yttria-stabilized zirconia using tape casting and laser-cut triangular patterns in some of the tapes. They employed cold isostatic pressing to sandwich solid layers between patterned layers and realized a new design. Their results indicated an enhancement in the performance of the fuel cells.

Although the above researchers were able to successfully fabricate parts with complex geometries using conventional manufacturing processes, Additive Manufacturing (AM) has a prominent advantage in fabricating complex parts with delicate geometrical features. Several studies have been conducted to exploit this advantage in fabricating parts from $8 \mathrm{~mol} \%$ yttriastabilized zirconia for SOFCs and other applications. Sukeshini et al. [11] used inkjet printing to fabricate electrolytes, as well as electrodes, for SOFCs. Their cells exhibited a maximum power density of 430 to $460 \mathrm{~mW} / \mathrm{cm}^{2}$ at $850{ }^{\circ} \mathrm{C}$ using hydrogen as the fuel source. Kirihara [12] built dendritic structures with geometrically ordered lattices using micro-patterning stereolithography with optimized process parameters, dewaxing, and sintering to achieve higher density. Tomov et al. [13] used direct inkjet printing and optimized the printing parameters to improve the surface quality of their parts. Manogharan et al. [14] employed binder jetting to fabricate parts. However, they were not able to fabricate dense components.

Although mechanical properties are of prime importance in many applications, to the authors' knowledge, there is no paper in the literature reporting the mechanical properties of additively manufactured, fully stabilized zirconia parts. In fact, AM of monolithic ceramics, which enables the components to match the physical and chemical properties of their conventionally manufactured counterparts, is still a challenge and remains the most important 
task that needs to be solved in order to promote AM of ceramics to more than a niche technology $[15]$.

In the current study, a novel extrusion-based AM process, called Ceramic On-Demand Extrusion (CODE), is used to produce $8 \mathrm{~mol} \%$ yttria-stabilized cubic zirconia parts. In this freeform fabrication process, aqueous suspensions of ceramic particles were prepared and extruded in a layer-by-layer fashion followed by uniform radiation drying between successive layers with a liquid surrounding the part. Density, hardness, fracture toughness, strength, stiffness and microstructure of fully stabilized zirconia parts were examined and compared to the properties of fully stabilized zirconia fabricated using traditional manufacturing methods.

\section{Materials and Methods}

\subsection{Feedstock preparation}

The feedstock of the CODE process is an extrudable, viscous colloid prepared by dispersing ceramic particles in an aqueous solution. This suspension is referred to as paste throughout this paper. The zirconia paste was made of a commercially available $8 \mathrm{~mol} \%$ yttria-stabilized zirconia (8YSZ) powder (TZ-8YS, Tosoh Corp., Grove City, OH, USA), deionized water, dispersant (Dolapix CE 64, Zschimmer \& Schwarz GmbH, Lahnstein, Germany), and 30\% $\mathrm{NH}_{3}$ basis ammonium hydroxide solution (221228, Sigma Aldrich, St. Louis, MO, USA) for pH adjustment. The zirconia powder had a specific surface area of $7 \mathrm{~m}^{2} / \mathrm{g}$ and an average particle size of $52 \mathrm{~nm}$ according to the manufacturer.

A nominally 50 vol\% solids loading paste was prepared by dispersing zirconia powder in water using $7.1 \mathrm{mg}$ dispersant per square meter of surface area of zirconia powder and adjusting the $\mathrm{pH}$ to $\sim 9$, as measured by a pH meter (HI 2210, Hannah Instruments, Woonsocket, RI, USA). A vacuum mixer (Model F, Whip Mix, Louisville, KY, USA) was employed to mix the paste 
homogeneously without introducing air bubbles. Finally, a vibratory table (Syntron Material Handling, Saltillo, MS, USA) was used to remove any remaining air bubbles.

\subsection{Fabrication process}

The CODE process is a freeform extrusion fabrication technique capable of making complex parts with near theoretical density ( $>98 \%)$. Ghazanfari et al. [16] introduced this process and employed it to produce several sample parts for various applications.

In the current study, eighteen "small blocks" (as-printed size: $25 \times 6 \times 4 \mathrm{~mm}^{3}$ in length, width, and height, respectively) and six "large blocks" (as-printed size: $60 \times 54 \times 7.5 \mathrm{~mm}^{3}$ in length, width, and height, respectively) were fabricated using the CODE process to examine the properties of the produced parts. Ceramic pastes were extruded through a circular nozzle that is mounted on a workhead attached to a gantry, which traversed in the $\mathrm{X}, \mathrm{Y}$ and $\mathrm{Z}$ directions through $\mathrm{G} \& \mathrm{M}$ code commands (i.e., $\mathrm{G} \& \mathrm{M}$ codes are a set of letters and numbers used to program the movements and other actions (tool change, end of program, etc.) of a $\mathrm{CNC}$ machine). The extrudate was deposited on a substrate located in a tank designed to hold a fluid medium (i.e., mineral oil). Once the deposition of each layer was completed, a liquid feeding subsystem pumped oil (Florasense Lamp Oil, MVP Group International Inc., Charleston, SC, USA) into the tank, surrounding the deposited layer, to preclude undesirable evaporation of water from the sides of the deposited layers. The level of the oil was controlled so that it reached just below the top surface of the part being fabricated. Infrared radiation was then used to uniformly dry the deposited layer so that the part being fabricated could maintain its shape when the next layers were being deposited as the part was being built. The parts were fabricated in a layer-by-layer fashion by repeating the layer deposition followed by radiation drying with a liquid surrounding the already deposited layers. Figure 1 shows a large block in the green state 
after the fabrication process. The process parameters used to print all the parts are given in Table 1. The processing time was $\sim 6$ min for each small block, and $\sim 65$ min for each large block.

\subsection{Drying and sintering}

After the fabrication process was completed, the samples were removed from the oil bath and their remaining water was eliminated using humid-drying. An environmental chamber (LH-1.5, Associated Environmental Systems, Ayer, MA, USA) was employed to control the temperature and humidity during the drying process at $25{ }^{\circ} \mathrm{C}$ and $75 \%$ relative humidity. This condition prevented warping and the formation of cracks during the drying process.

The dried parts were then sintered in an electric furnace (Deltech Inc., Denver, CO, USA). To determine the optimal sintering conditions, the eighteen small blocks were divided into six groups and sintered under six different conditions as discussed in Section 3.1. Based on a comparison of the properties of these six groups, two sintering conditions were chosen to sinter the six large blocks and study their properties.

\subsection{Characterization}

Archimedes' technique was performed to measure the density of the printed parts after sintering. After the dry mass was recorded, samples were saturated by submersion in distilled water under vacuum for $\sim 12 \mathrm{~h}$. The saturated and suspended masses were then measured to calculate the bulk density. This value was divided by the theoretical density of $8 \mathrm{YSZ}\left(5.97 \mathrm{~g} / \mathrm{cm}^{3}\right.$ [17]) to find the average relative density of the samples. The size of the blocks was measured after printing, drying, and sintering to calculate the amount of shrinkage during the bulk drying and sintering processes.

Microstructural images were obtained using Scanning Electron Microscopy (SEM) from sections of the sintered test blocks. Specimens were polished to a $0.25 \mu \mathrm{m}$ diamond finish using 
successively finer diamond abrasives. Thermal etching was then used to reveal the grain boundaries by placing the polished specimens in an electric furnace (Deltech Inc., Denver, CO, USA) at $1350{ }^{\circ} \mathrm{C}$ for $30 \mathrm{~min}$ with a heating/cooling rate of $10^{\circ} \mathrm{C} / \mathrm{min}$. A scanning electron microscope (Helios Nanolab 600, FEI, Hillsboro, OR, USA) was employed to observe the specimens.

Vickers indentation test was carried out according to ASTM C1327 [18] using a microhardness tester (Duramin 5; Struers, Cleveland, OH, USA) to measure the hardness. The samples were polished to a $0.25 \mu \mathrm{m}$ diamond finish using successively finer diamond abrasives. Hardness was calculated from 4 to 6 indents per sample. The indenter was pressed against the samples with a force of $4.91 \mathrm{~N}$ for $10 \mathrm{~s}$. The indentation size was measured using an optical microscope with a $40 \mathrm{X}$ lens.

Fracture toughness was measured at room temperature by two methods. For the small blocks, it was estimated from the hardness tests by measuring the length of cracks extending from the corners of the Vickers indent as discussed in Section 3.1. For the large blocks, it was measured using chevron-notched beam specimens in four-point bending using a fully articulating test fixture for configuration $\mathrm{A}\left(\mathrm{L}=50 \mathrm{~mm}, \mathrm{~B}=3 \mathrm{~mm}, \mathrm{~W}=4 \mathrm{~mm}\right.$, and $\mathrm{a}_{0}=0.8 \mathrm{~mm}$ ) according to ASTM C1421 [19]. Eight test bars were ground to standard size for each group using a fully automated surface grinder (Chevalier, FSG-3A818, Santa Fe Springs, CA, USA). The chevron notches were machined using a dicing saw (Accu-cut 5200, Aremco Products, Ossining, NY, USA) with a $0.15 \mathrm{~mm}$-thick diamond wafering blade. The same fixture and load frame used for flexural tests were employed to break the chevron-notched beams with a crosshead speed of $0.015 \mathrm{~mm} / \mathrm{min}$. The notch dimensions were then measured using an optical microscope (KH-3000, Hirox, Hackensack, NJ, USA). 
Four-point bending tests were performed at room temperature according to ASTM C1161 [20] to measure flexural strengths. The same surface grinder employed for chevron-notched beam specimens was used to machine the specimens to standard "B" bars $\left(3 \times 4 \times 45 \mathrm{~mm}^{3}\right)$. All the surfaces of the bars were machined with a 600 -grit diamond abrasive wheel. The bars were then manually chamfered using a 1200-grit metal-bond diamond grinding disk. Flexural strengths were measured using a fully articulating B-bar fixture with an outer span of $40 \mathrm{~mm}$ and an inner span of $20 \mathrm{~mm}$ in a screw-driven instrumented load frame (5881; Instron, Norwood, MA, USA). The crosshead speed was $0.5 \mathrm{~mm} / \mathrm{min}$. Young's modulus was determined using a deflectometer (a linear variable differential transformer) measuring the deflection of the center of the test bar during strength testing (deflectometer's data was recorded from the beginning of each test until the failure of the specimen).

\section{Results and Discussion}

\subsection{Sintering study}

The 18 small blocks were sintered under 6 different conditions as given in Table 2. Their properties were evaluated in order to choose the best sintering condition for the large blocks. Their relative density was measured to be $99 \pm 0.2 \%$ regardless of their sintering conditions. Thus, they were judged based on hardness and fracture toughness. The values of hardness are given in Table 2 for each group. Groups 3 and 6 had the highest hardness values (15.3 $\pm 0.4 \mathrm{GPa}$ and 15.4 $\pm 0.2 \mathrm{GPa}$, respectively). To compare the fracture toughness, the equation proposed by Liang et al. [21] was chosen due to its popularity for zirconia [22-32]. According to their method, the value of fracture toughness is estimated from the following equation:

$$
\left(\frac{K_{I C} \varphi}{H a^{0.5}}\right)\left(\frac{H}{E \varphi}\right)^{0.4} \alpha=\left(\frac{c}{a}\right)^{(c / 18 a)-1.51}
$$


where $K_{I C}$ is the fracture toughness in $\mathrm{MPa} \cdot \mathrm{m}^{0.5}, H$ is the hardness in MPa, $E$ is the Young's modulus in $\mathrm{MPa}, \varphi$ is a constant equal to 3 , and $a$ and $c$ are the half diagonal length of the indent and half length of the crack in $\mathrm{m}$, respectively. $\alpha$ is obtained from Equation (2):

$$
\alpha=14\left[1-8\left(\frac{4 v-0.5}{1+v}\right)^{4}\right]
$$

where $v$ is Poisson's ratio which was assumed to be 0.29 [22-32].

The values of fracture toughness are given in Table 2 for each group. An indented sample is shown in Figure 2. Groups 2 and 4 had the highest toughness values $\left(3.62 \pm 0.17 \mathrm{MPa} \cdot \mathrm{m}^{0.5}\right.$ and $3.61 \pm 0.08 \mathrm{MPa} \cdot \mathrm{m}^{0.5}$, respectively). Accordingly, the sintering schedules of Groups 3 and 4 were chosen, based on a combination of hardness and fracture toughness, to sinter the large blocks. It is noted that Groups 2 and 4 had almost identical properties and Group 4 was chosen only because it had a different sintering temperature from Group 3. Three of the large blocks were sintered with the same sintering schedule as Group 3, and the other three were sintered with the same conditions as Group 4.

Figure 3 shows representative microstructures of specimens from Groups 3, 4, and 6 . The grains were equiaxed, intergranular porosity was not observed, and intragranular pores were small $(<1 \mu \mathrm{m})$. Grain size was measured by the lineal intercept method. Twenty horizontal lines, with random distances relative to each other, were constructed on the image of microstructure. The length of the lines was equal to the width of the image and each line had 20 to 30 interceptions with grain boundaries. The grain size was estimated using the following equation.

$$
D=1.56 \frac{\sum l_{i}}{\sum n_{i}}
$$


where $D$ is the average grain size in $\mu \mathrm{m}, l_{i}$ is the length of each line in $\mu \mathrm{m}$, and $n_{i}$ is the number of interceptions for each line. An average grain size of 5.1, 6.1, and $7.3 \mu \mathrm{m}$ was determined using this method for Group 3, 4, and 6, respectively.

\subsection{Shrinkage}

The size of the large blocks reduced to $58.5 \times 53.2 \times 7.3 \mathrm{~mm}^{3}$ after drying, showing $2.5 \%, 1.5 \%$ and $2.7 \%$ reduction in length, width and height, respectively. This indicates a volumetric shrinkage of $6.5 \%$. The dimensions of the bars were $46.8 \times 42.6 \times 5.7 \mathrm{~mm}^{3}$ after sintering, showing $22.0 \%, 21.1 \%$ and $24.0 \%$ reduction in length, width and height, respectively, compared to the wet (as-printed) samples. This indicates a volumetric shrinkage of 53.2\% compared to wet samples. The slightly lower shrinkage percentage in the length and width directions, during drying and sintering, is hypothesized to be caused by friction between specimen and substrates, which hinders shrinkage; i.e. due to friction, it is more difficult for particles to move in the longitudinal and transverse directions of the parts than the thickness direction. However, further evidence is required to confirm this conjecture. The amounts of shrinkage during each step are given in Table 3.

\subsection{Properties}

To calculate Young's modulus, Equation (4), which was obtained from Euler-Bernoulli beam theory (see e.g. [33] for an explanation of this theory), was used.

$$
E=\frac{11 P l^{3}}{768 I \delta}
$$

where $E$ is Young's modulus $\left(\mathrm{N} / \mathrm{m}^{2}\right), P$ is the total load measured by a load cell $(\mathrm{N}), l$ is the outer span of the fixture (m), $I$ is the second moment of inertia of the test specimen's cross-section about the neutral axis $\left(\mathrm{m}^{4}\right)$, and $\delta$ is the mid-span deflection measured by the deflectometer (m). 
For a rectangular cross-section with four chamfered edges of size $c$, the adjusted moment of inertia is given in [20]:

$$
I=\frac{b d^{3}}{12}-\frac{c^{2}}{9}\left(c^{2}+\frac{(3 d-2 c)^{2}}{2}\right)
$$

where $b$ and $d$ are width and height of the bar (m), respectively, and $c$ is the chamfer size (m). Based on this calculation, Young's modulus of Group 3 and 4 specimens were $195 \pm 8$ and $208 \pm 6$ $\mathrm{GPa}$, respectively. This is in agreement with reported values in the literature ranging from 190 to $205 \mathrm{GPa}[8,31,34,35]$.

The hardness values measured were $15.3 \pm 0.4$ and $14.5 \pm 0.2$ GPa for Group 3 and 4, respectively. These values are given in Table 4 along with values found in the literature for material produced by cold isostatic pressing and sintered. The hardness of parts produced by the CODE process are close to the upper limit of the data range found in the literature for 8YSZ (11 to $16 \mathrm{GPa})[31,36-39]$.

In the literature, the fracture toughness of $8 \mathrm{YSZ}$ ceramics has commonly been measured based on indentation tests, which is not an ASTM standard method and may result in large errors. As an example, Kibsey et al. [27] reported that, for the same sample, the predicted value of fracture toughness obtained from seven common equations varied between 2.3 and 13.5 $\mathrm{MPa} \cdot \mathrm{m}^{0.5}$. Quinn and Bradt [40] also recommended that the indentation fracture toughness technique no longer be acceptable for ceramic materials. For 8YSZ, the reported data were in the range of 1.3 to $5.1 \mathrm{MPa} \cdot \mathrm{m}^{0.5}[31,36,38,39]$ as given in Table 4. This large variation is due to different equations used to estimate the fracture toughness based on indentation data, not because of the variations in material properties. Therefore, it is not possible to make a fair comparison 
between different groups. Nevertheless, if the same equation is used to estimate the fracture toughness for two sets of samples, the result is acceptable to make a comparison.

In addition to indentation fracture tests, the results of the chevron notch method are also given in Table 4. Based on this standard method, Group 3 and 4 had a fracture toughness of $2.1 \pm 0.1$ and $2.5 \pm 0.1 \mathrm{MPa} \cdot \mathrm{m}^{0.5}$, respectively (compare with $3.02 \pm 0.24$ and $3.61 \pm 0.08 \mathrm{MPa} \bullet \mathrm{m}^{0.5}$ estimated by indentation technique for Group 3 and 4, respectively). It should be noted that for 8YSZ samples, it was difficult to initiate a stable crack from the tip of the chevron notch even after a slow crosshead speed and a compression-compression fatiguing procedure was used as suggested by ASTM C1421. Only three specimens experienced a stable crack growth in each group and the fracture toughness was calculated based on these specimens (i.e., data from unstable cracks were discarded).

The average flexural strengths were $232 \pm 55$ and $278 \pm 59 \mathrm{MPa}$ for Group 3 and 4, respectively. The test data are shown in Figure 4. For brittle materials, the measured value of strength greatly depends on test methodology and it is not fair to make a direct comparison between reported values from different sources if the test methodologies are not the same. For example, An et al. [34] cut square plates and round disks of two different diameters from identical plates made of zirconia and used three standard test methods to evaluate their strength. They reported strengths of 139,483 , and $894 \mathrm{MPa}$ for the tensile, pressure-on-ring, and ball-onring tests, respectively. The only way to compare the results of different tests is to convert the data as explained in ASTM 1683 [41]. This method requires all the dimensions of samples and test fixture as well as Weibull modulus. Unfortunately, these values are not reported for 8YSZ in most papers and it is not possible to convert their data to those of four-point bending test. Accordingly, the flexural strength of samples in the current study was only compared to 
available data in literature for four-point bending tests of 8YSZ (typically 250 to $330 \mathrm{MPa}$ [2,4245]).

Detailed discussions about advantages, disadvantages, applications, fabrication of geometrically complex parts and properties of other materials produced via CODE process can be found elsewhere [16,46-48].

\section{Conclusions}

A novel freeform extrusion fabrication process was employed to produce highly dense (with a relative density of $>99 \%$ ) parts from 8 mol\% yttria-stabilized zirconia. Properties of these parts were studied using standard test methods and compared to those from other processes. Six sintering schedules were examined and two of them were chosen, based on their hardness and indentation fracture toughness, to produce final parts. The first group of final parts had a hardness of $15.3 \pm 0.4 \mathrm{GPa}$ and an average flexural strength of $232 \pm 55 \mathrm{MPa}$, while the second group had a hardness of $14.5 \pm 0.2 \mathrm{GPa}$ and an average flexural strength of $278 \pm 59 \mathrm{MPa}$.

To the authors' knowledge, other additive manufacturing processes have not been able to produce near theoretically dense, high strength parts or test bars from fully stabilized zirconia. Therefore, the results of this study were compared to traditional fabrication methods. All the properties including density, strength, hardness, fracture toughness, and Young's modulus matched the data found in literature for fabrication of fully stabilized zirconia using conventional techniques.

\section{Acknowledgements}

This work was supported by the National Energy Technology Laboratory of the U.S. Department of Energy's Office of Fossil Energy (grant number DE-FE0012272), and the Intelligent Systems Center at the Missouri University of Science and Technology. Mr. Ryan 
Grohsmeyer's help in performing flexural tests and Mr. Devin McMillen's help in paste preparation are greatly appreciated.

\section{References}

[1] P. Boch, J.C. Niepce, eds., Ceramic materials: processes, properties and applications, 1st ed., ISTE USA, Newport Beach, CA, USA, 2007.

[2] S.P.S. Badwal, F.T. Ciacchi, V. Zelizko, The effect of alumina addition on the conductivity, microstructure and mechanical strength of zirconia - yttria electrolytes, Ionics (Kiel). 4 (1998) 25-32. doi:10.1007/BF02375776.

[3] W. Winkler, The influence of the mass transfer on the geometric design of SOFC stacks, J. Power Sources. 86 (2000) 449-454. doi:10.1016/S0378-7753(99)00452-8.

[4] F. Fleischhauer, R. Bermejo, R. Danzer, A. Mai, T. Graule, J. Kuebler, Strength of an electrolyte supported solid oxide fuel cell, J. Power Sources. 297 (2015) 158-167. doi:10.1016/j.jpowsour.2015.07.075.

[5] D. Beeaff, G. Hilmas, Electrode support structures for planar solid oxide fuel cells, Key Eng. Mater. 264 (2004) 747-750. doi:10.4028/www.scientific.net/KEM.264-268.747.

[6] J. Ding, J. Liu, A novel design and performance of cone-shaped tubular anode-supported segmented-in-series solid oxide fuel cell stack, J. Power Sources. 193 (2009) 769-773. doi:10.1016/j.jpowsour.2009.04.049.

[7] T. Yamaguchi, S. Shimizu, T. Suzuki, Y. Fujishiro, M. Awano, Design and fabrication of a novel electrode-supported honeycomb SOFC, J. Am. Ceram. Soc. 92 (2009) 107-111. doi:10.1111/j.1551-2916.2008.02688.x. 
[8] J.C. Ruiz-Morales, D. Marrero-López, J. Peña-Martínez, J. Canales-Vázquez, J.J. Roa, M. Segarra, S.N. Savvin, P. Núñez, Performance of a novel type of electrolyte-supported solid oxide fuel cell with honeycomb structure, J. Power Sources. 195 (2010) 516-521. doi:10.1016/j.jpowsour.2009.08.017.

[9] K. Rajeswari, P. Biswas, M.B. Suresh, U.S. Hareesh, R. Johnson, D. Das, Colloidal shaping of $8 \mathrm{~mol} \%$ yttria-stabilized zirconia electrolyte honeycomb structures by microwave-assisted thermal gelation of methyl cellulose, Int. J. Appl. Ceram. Technol. 11 (2014) 154-163. doi:10.1111/j.1744-7402.2012.02852.x.

[10] S. Celik, B. Timurkutluk, S. Toros, C. Timurkutluk, Mechanical and electrochemical behavior of novel electrolytes based on partially stabilized zirconia for solid oxide fuel cells, Ceram. Int. 41 (2015) 8785-8790. doi:10.1016/j.ceramint.2015.03.104.

[11] A.M. Sukeshini, R. Cummins, T.L. Reitz, R.M. Miller, Inkjet printing of anode supported SOFC: comparison of slurry pasted cathode and printed cathode, Electrochem. Solid-State Lett. 12 (2009) 176-179. doi:10.1149/1.3243468.

[12] S. Kirihara, Creation of functional ceramics structures by using stereolithographic 3D printing, Trans. JWRI. 43 (2014) 5-10.

[13] R.I. Tomov, M. Krauz, J. Jewulski, S.C. Hopkins, J.R. Kluczowski, D.M. Glowacka, B.A. Glowacki, Direct ceramic inkjet printing of yttria-stabilized zirconia electrolyte layers for anode-supported solid oxide fuel cells, J. Power Sources. 195 (2010) 7160-7167. doi:10.1016/j.jpowsour.2010.05.044.

[14] G. Manogharan, M. Kioko, C. Linkous, Binder jetting: a novel solid oxide fuel-cell 
fabrication process and evaluation, JOM. 67 (2015) 660-667. doi:10.1007/s11837-015$1296-9$.

[15] A. Zocca, P. Colombo, C.M. Gomes, J. Günster, Additive manufacturing of ceramics: issues, potentialities, and opportunities, J. Am. Ceram. Soc. 98 (2015) 1983-2001. doi:10.1111/jace.13700.

[16] A. Ghazanfari, W. Li, M.C. Leu, G.E. Hilmas, A novel extrusion-based additive manufacturing process for ceramic parts, in: D.L. Bourell, R.H. Crawford, C.C. Seepersad, J.J. Beaman, S. Fish, H. Marcus (Eds.), Solid Free. Fabr. Symp., Austin, TX, USA, 2016: pp. 1509-1529.

[17] R.P. Ingel, D. Lewis III, Lattice parameters and density for Y2O3-stabilized $\mathrm{ZrO} 2$, J. Am. Ceram. Soc. 69 (1986) 325-332. doi:10.1111/j.1151-2916.1986.tb04741.x.

[18] ASTM C1327, Standard test method for Vickers indentation hardness of advanced ceramics, West Conshohocken, PA, USA, 2015. doi:10.1520/C1327-15.

[19] ASTM C1421, Standard test methods for determination of fracture toughness of advanced ceramics, West Conshohocken, PA, USA, 2010. doi:10.1520/C1421-10.

[20] ASTM C1161, Standard test method for flexural strength of advanced ceramics at ambient temperatures, West Conshohocken, PA, USA, 2013. doi:10.1520/C1161-13.

[21] K.M. Liang, G. Orange, G. Fantozzi, Evaluation by indentation of fracture toughness of ceramic materials, J. Mater. Sci. 25 (1990) 207-214. doi:10.1007/BF00544209.

[22] K. Tada, M. Watanabe, Y. Tachi, H. Kurishita, S. Nagata, T. Shikama, Fast reactor irradiation effects on fracture toughness of Si3N4 in comparison with $\mathrm{MgAl} 2 \mathrm{O} 4$ and yttria 
stabilized ZrO2, J. Nucl. Mater. 471 (2016) 69-73. doi:10.1016/j.jnucmat.2015.12.026.

[23] O.S. Fakolujo, Characterisation and properties improvement of armour ceramics, University of Ottawa, 2016.

[24] I. Danilenko, F. Glazunov, T. Konstantinova, G. Volkova, V. Burkhovetski, Effect of oxide nanofillers on fabrication, structure, and properties of zirconia-based composites, J. Eur. Ceram. Soc. 33 (2013) 2321-2325. doi:10.1016/j.jeurceramsoc.2013.01.039.

[25] F. Sahnoune, N. Saheb, P. Goeuriot, Properties of Mullite-Zirconia Composites Prepared through Reaction Sintering Kaolin, $\alpha-\mathrm{Al} 2 \mathrm{O} 3$, and ZrO2, Adv. Mater. Res. 160-162 (2011) 1772-1778. doi:10.4028/www.scientific.net/AMR.160-162.1772.

[26] J.E. Petitjean, X. Huang, R.M. Kearsey, Fracture toughness KIC analysis of Co-doped 7YSZ, Mater. Sci. Technol. 27 (2011) 1606-1609. doi:10.1179/026708310X12756557336319.

[27] M. Kibsey, J. Romualdez, X. Huang, R. Kearsey, Q. Yang, Mechanical properties of titania-doped yttria stabilized zirconia (TiYSZ) for use as thermal barrier coating (TBC), J. Eng. Gas Turbines Power. 133 (2011) 122101. doi:10.1115/1.4004125.

[28] P.P. Shukla, J. Lawrence, H. Wu, Fracture toughness of a zirconia engineering ceramic and the effects thereon of surface processing with fibre laser radiation, Proc. Inst. Mech. Eng. Part B J. Eng. Manuf. 224 (2010) 1555-1569. doi:10.1243/09544054JEM1887.

[29] F. Sahnoune, N. Saheb, Mechanical behavior of mullite-zirconia composites, EPJ Web Conf. 6 (2010). http://dx.doi.org/10.1051/epjconf/20100620005.

[30] D. Chicot, G. Duarte, A. Tricoteaux, B. Jorgowski, A. Leriche, J. Lesage, Vickers 
Indentation Fracture (VIF) modeling to analyze multi-cracking toughness of titania, alumina and zirconia plasma sprayed coatings, Mater. Sci. Eng. A. 527 (2009) 65-76. doi:10.1016/j.msea.2009.08.058.

[31] A. Ghosh, A.K. Suri, B.T. Rao, T.R. Ramamohan, Low-temperature sintering and mechanical property evaluation of nanocrystalline $8 \mathrm{~mol} \%$ yttria fully stabilized zirconia, J. Am. Ceram. Soc. 90 (2007) 2015-2023. doi:10.1111/j.1551-2916.2007.01683.x.

[32] L.B. Garrido, E.F. Aglietti, L. Martorello, M.A. Camerucci, A.L. Cavalieri, Hardness and fracture toughness of mullite-zirconia composites obtained by slip casting, Mater. Sci. Eng. A. 419 (2006) 290-296. doi:10.1016/j.msea.2006.01.035.

[33] M.H. Sadd, Elasticity: theory, applications, and numerics, second edi, Elsevier, Burlington, MA, USA, 2009.

[34] K. An, H.G. Halverson, K.L. Reifsnider, S.W. Case, M.H. Mccord, Comparison of methodologies for determination of fracture strength of $8 \mathrm{~mol} \%$ yttria-stabilized zirconia electrolyte materials, J. Fuel Cell Sci. Technol. 2 (2005) 99-103. doi:10.1115/1.1867974.

[35] J. Kondoh, Aging strengthening of $8 \mathrm{~mol} \%$ yttria-fully-stabilized zirconia, J. Alloys Compd. 370 (2004) 285-290. doi:10.1016/j.jallcom.2003.09.025.

[36] S. Tekeli, The flexural strength, fracture toughness, hardness and densification behaviour of various amount of Al2O3-doped 8YSCZ/A12O3 composites used as an electrolyte for solid oxide fuel cell, Mater. Des. 27 (2006) 230-235. doi:10.1016/j.matdes.2004.10.011.

[37] S. Heiroth, R. Ghisleni, T. Lippert, J. Michler, A. Wokaun, Optical and mechanical properties of amorphous and crystalline yttria-stabilized zirconia thin films prepared by 
pulsed laser deposition, Acta Mater. 59 (2011) 2330-2340.

doi:10.1016/j.actamat.2010.12.029.

[38] A.G. Mawson, G.A. Carter, R.D. Hart, N.M. Kirby, A.C. Nachmann, Mechanical properties of $8 \mathrm{~mol} \%$ yttria-stabilised zirconia for solid oxide fuel cells, Mater. Forum. 30 (2006) 148-158.

[39] M. Mazaheri, A.M. Zahedi, M.M. Hejazi, Processing of nanocrystalline 8 mol\% yttriastabilized zirconia by conventional, microwave-assisted and two-step sintering, Mater. Sci. Eng. A. 492 (2008) 261-267. doi:10.1016/j.msea.2008.03.023.

[40] G.D. Quinn, R.C. Bradt, On the vickers indentation fracture toughness Test, J. Am. Ceram. Soc. 90 (2007) 673-680. doi:10.1111/j.1551-2916.2006.01482.x.

[41] ASTM C1683, Standard practice for size scaling of tensile strengths using Weibull statistics for advanced ceramics, West Conshohocken, PA, USA, 2015. doi:10.1520/C1683-10R15.

[42] F.L. Lowrie, R.D. Rawlings, Room and high temperature failure mechanisms in solid oxide fuel cell electrolytes, J. Eur. Ceram. Soc. 20 (2000) 751-760. doi:10.1016/S09552219(99)00080-1.

[43] S.P.S. Badwal, F.T. Ciacchi, Oxygen-ion conducting electrolyte materials for solid oxide fuel cells, Ionics (Kiel). 6 (2000) 1-21. doi:10.1007/BF02375543.

[44] I.R. Gibson, G.P. Dransfield, J.T.S. Irvine, Influence of yttria concentration upon electrical properties and susceptibility to ageing of yttria-stabilised zirconias, J. Eur. Ceram. Soc. 18 (1998) 661-667. doi:10.1016/S0955-2219(97)00173-8. 
[45] F.T. Ciacchi, K.M. Crane, S.P.S. Badwal, Evaluation of commercial zirconia powders forsolid oxide fuel cells, Solid State Ionics. 73 (1994) 49-61. doi:10.1016/01672738(94)90263-1.

[46] A. Ghazanfari, W. Li, M.C. Leu, Y. Zhuang, J. Huang, Advanced ceramic components with embedded sapphire optical fiber sensors for high temperature applications, Mater. Des. 112 (2016) 197-206. doi:10.1016/j.matdes.2016.09.074.

[47] W. Li, A. Ghazanfari, M.C. Leu, R.G. Landers, Methods of extrusion on demand for high solids loading ceramic paste in freeform extrusion fabrication, in: D. Bourell, J. Beaman, R. Crawford, S. Fish, H. Marcus, C. Seepersad (Eds.), Solid Free. Fabr. Symp., Austin, TX, USA, 2015: pp. 332-345.

[48] W. Li, A. Ghazanfari, D. McMillen, M.C. Leu, G.E. Hilmas, J.L. Watts, Properties of partially stabilized zirconia components fabricated by the ceramic on-demand extrusion process, in: D.L. Bourell, R.H. Crawford, C.C. Seepersad, J.J. Beaman, S. Fish, H. Marcus (Eds.), Solid Free. Fabr. Symp., Austin, TX, USA, 2016: pp. 916-928. 


\section{Figure Captions}

Figure 1. A sample block $\left(60 \times 54 \times 7.5 \mathrm{~mm}^{3}\right)$ after fabrication using the CODE process.

Figure 2. An indented sample used to measure hardness and indentation fracture toughness.

Figure 3. SEM images showing representative microstructures of fully stabilized zirconia parts produced using the CODE process: (a) Group 3, (b) Group 4, and (c) Group 6.

Figure 4. Flexural test data for Group 3 and 4 (the average values are 232 and $278 \mathrm{MPa}$, respectively). 
Table 1. Printing parameters used in the CODE process to fabricate fully stabilized zirconia test blocks.

\begin{tabular}{|c|c|}
\hline Nozzle diameter $(\boldsymbol{\mu m})$ & 610 \\
\hline Nozzle travel speed $(\mathbf{m m} / \mathbf{s})$ & 30 \\
\hline Layer thickness $(\boldsymbol{\mu m})$ & 400 \\
\hline Number of layers & 19 \\
\hline Line spacing $(\boldsymbol{\mu m})$ & 600 \\
\hline Number of lines in a layer & 90 \\
\hline Lamp distance (m) & 0.25 \\
\hline Radiation time (s) & 30 \\
\hline
\end{tabular}


Table 2. Schedules used in the sintering study and the corresponding hardness and toughness.

\begin{tabular}{|c|c|c|c|c|c|c|}
\hline \multirow{2}{*}{ Group } & \multicolumn{4}{|c|}{ Sintering condition } & \multirow{2}{*}{$\begin{array}{c}\text { Vickers } \\
\text { hardness } \\
\text { (GPa) }\end{array}$} & \multirow{2}{*}{$\begin{array}{l}\text { Indentation } \\
\text { fracture } \\
\text { toughness } \\
\left(\mathrm{MPa} \cdot \mathrm{m}^{0.5}\right)\end{array}$} \\
\hline & $\begin{array}{l}\text { Heating rate } \\
\qquad\left({ }^{\circ} \mathrm{C} / \mathrm{min}\right)\end{array}$ & $\begin{array}{c}\text { Sintering } \\
\text { temperature }\left({ }^{\circ} \mathrm{C}\right)\end{array}$ & Hold time (h) & $\begin{array}{l}\text { Cooling rate } \\
\left({ }^{\circ} \mathrm{C} / \mathrm{min}\right)\end{array}$ & & \\
\hline 1 & 5 & 1500 & 1 & 2 & $14.3 \pm 0.3$ & $3.37 \pm 0.09$ \\
\hline 2 & 5 & 1500 & 1.5 & 2 & $14.5 \pm 0.2$ & $3.62 \pm 0.17$ \\
\hline 3 & 5 & 1500 & 2.5 & 10 & $15.3 \pm 0.4$ & $3.02 \pm 0.24$ \\
\hline 4 & 5 & 1550 & 0.5 & 2 & $14.5 \pm 0.2$ & $3.61 \pm 0.08$ \\
\hline 5 & 5 & 1550 & 0.8 & 10 & $14.3 \pm 0.1$ & $3.50 \pm 0.16$ \\
\hline 6 & 5 & 1600 & 0.5 & 10 & $15.4 \pm 0.2$ & $2.95 \pm 0.11$ \\
\hline
\end{tabular}


Table 3. Amount of shrinkage of large blocks at each stage.

\begin{tabular}{|c|c|c|c|}
\hline & Size $\mathbf{( m m )}$ & Linear shrinkage & Volumetric \\
\hline As-printed & $60 \times 54 \times 7.5$ & $\mathbf{( \% )}$ & shrinkage (\%) \\
\hline Dried & $58.5 \times 53.2 \times 7.3$ & $2.5 \times 1.5 \times 2.7$ & - \\
\hline Sintered & $46.8 \times 42.6 \times 5.7$ & $22.0 \times 21.1 \times 24.0$ & 5.5 \\
\hline
\end{tabular}


Table 4. Mechanical properties of 8YSZ produced via CODE and traditional techniques.

\begin{tabular}{|c|c|c|c|c|}
\hline Process & $\begin{array}{c}\text { Flexural } \\
\text { strength } \\
\text { (MPa) }\end{array}$ & $\begin{array}{c}\text { Hardness } \\
\text { (GPa) }\end{array}$ & $\begin{array}{l}\text { Fracture } \\
\text { toughness }^{*} \\
\left(\mathrm{MPa} \cdot \mathbf{m}^{0.5}\right)\end{array}$ & $\begin{array}{c}\text { Indentation } \\
\text { fracture toughness } \\
\left(\mathrm{MPa} \cdot \mathrm{m}^{0.5}\right)\end{array}$ \\
\hline CODE (Group 3) & $232 \pm 55^{* *}$ & $15.3 \pm 0.4$ & $2.1 \pm 0.1$ & $3.02 \pm 0.24$ \\
\hline CODE (Group 4) & $278 \pm 59^{* *}$ & $14.5 \pm 0.2$ & $2.5 \pm 0.1$ & $3.61 \pm 0.08$ \\
\hline $\mathrm{CIP}^{\dagger}[31]$ & - & $11 \pm 0.9$ & - & $5.1 \pm 1.1$ \\
\hline $\mathrm{CIP}^{\dagger}[36]$ & $275^{*}$ & 13 & - & $1.5 \pm 0.03$ \\
\hline $\mathrm{CIP}^{\dagger}[38]$ & $262 \pm 27^{* *}$ & $11.9 \pm 0.4$ & - & $1.3 \pm 0.1$ \\
\hline $\mathrm{CIP}^{\dagger}[39]$ & - & $13.5 \pm 0.2$ & - & $3.16 \pm 0.06$ \\
\hline $\begin{array}{c}\mathrm{CIP}^{\dagger} \text { and microwave } \\
\text { sintering [39] }\end{array}$ & - & $13.7 \pm 0.2$ & - & $3.17 \pm 0.10$ \\
\hline $\begin{array}{l}{ }^{*} \text { From chevron-notched } \\
\text { Four-point bending tes } \\
\text { Cold Isostatic Pressing } \\
\text { Three-point bending tes }\end{array}$ & tandard " $\mathrm{B}$ & $\begin{array}{l}\text { 3" bars acco } \\
\mathrm{f} 30 \mathrm{~mm} \text { and }\end{array}$ & rding to ASTI & of $3 \times 4 \mathrm{~mm}^{2}$ \\
\hline
\end{tabular}




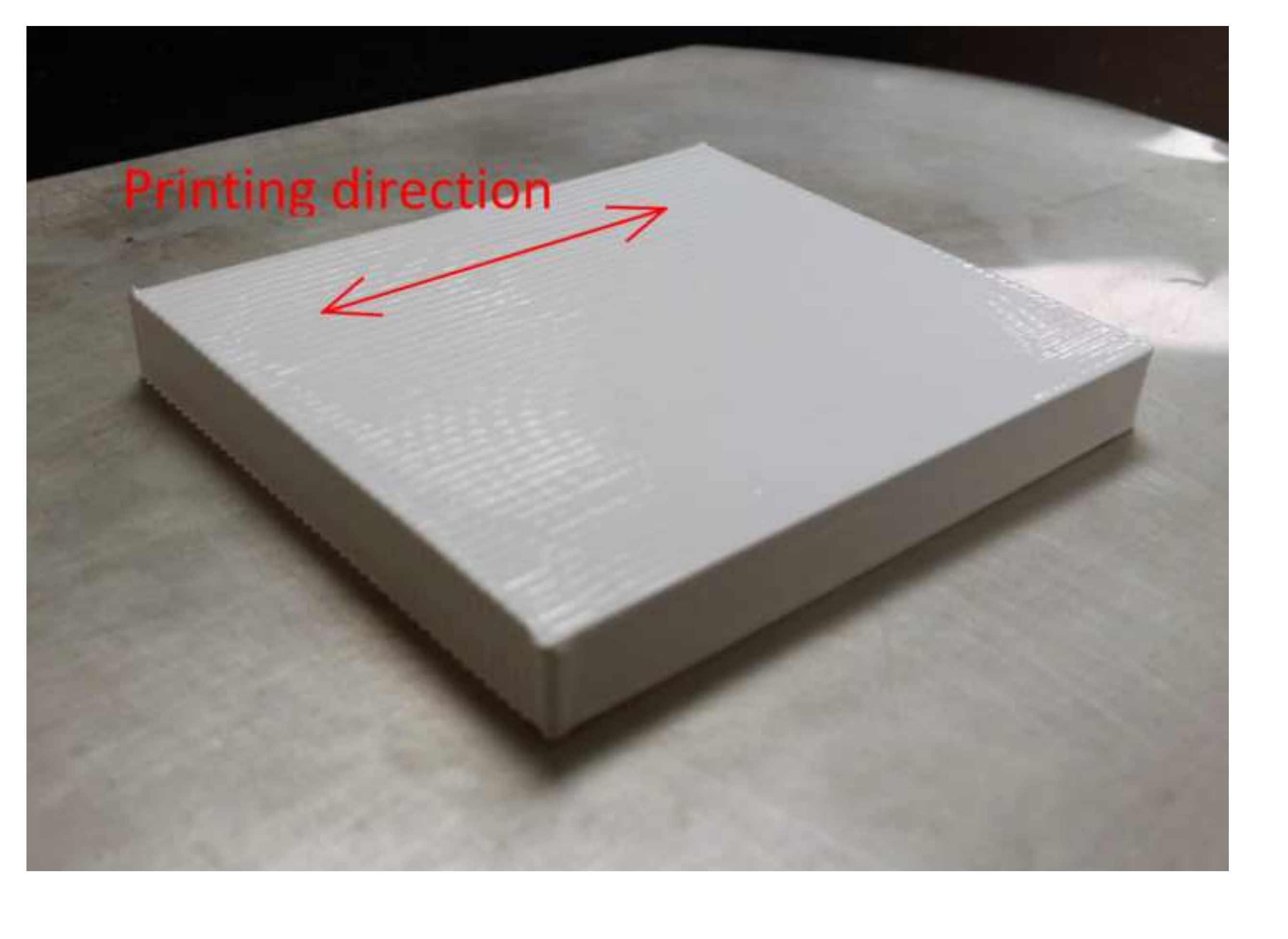

Figure 1

Figure
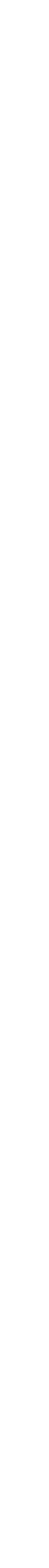

.
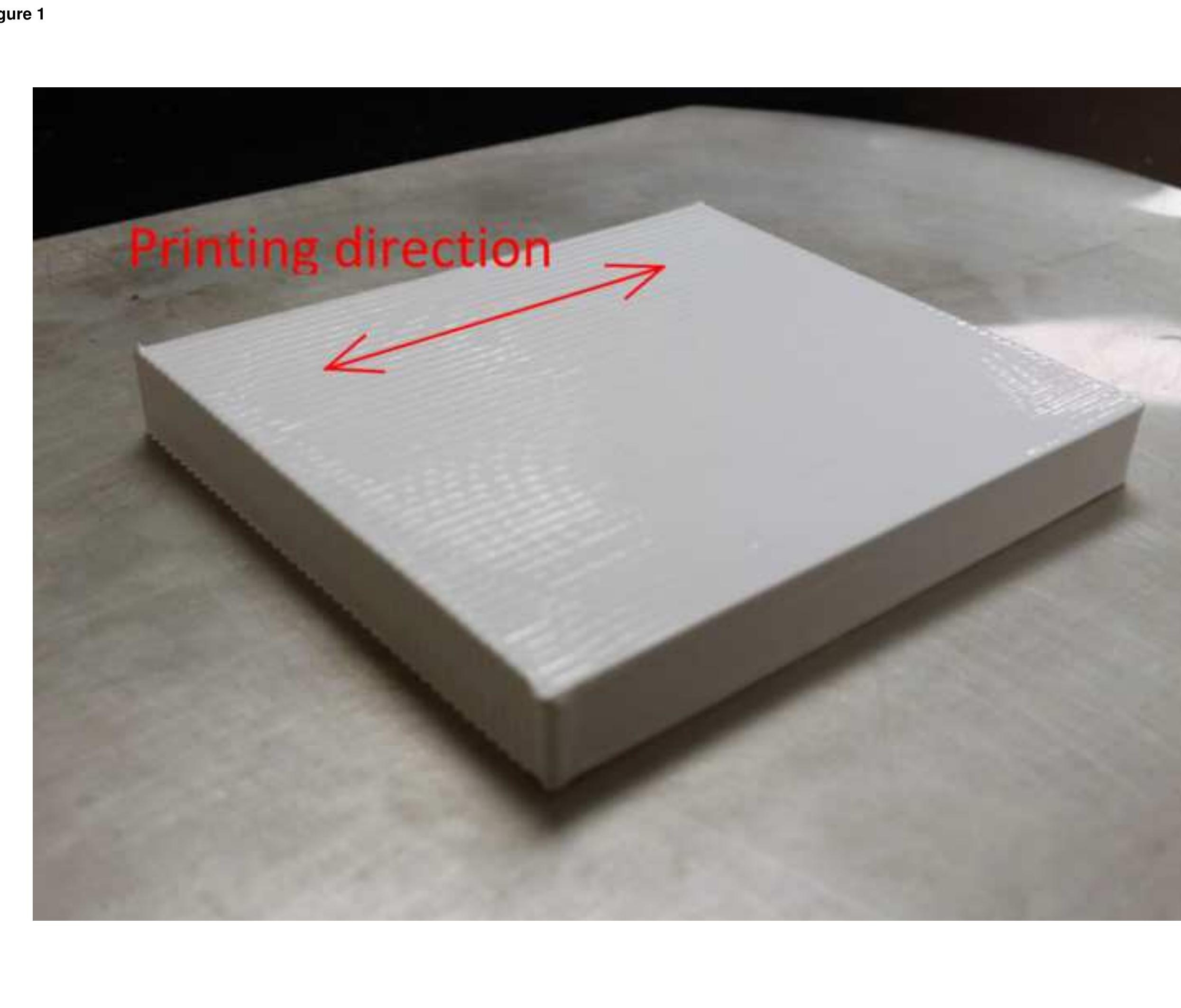
Figure 2

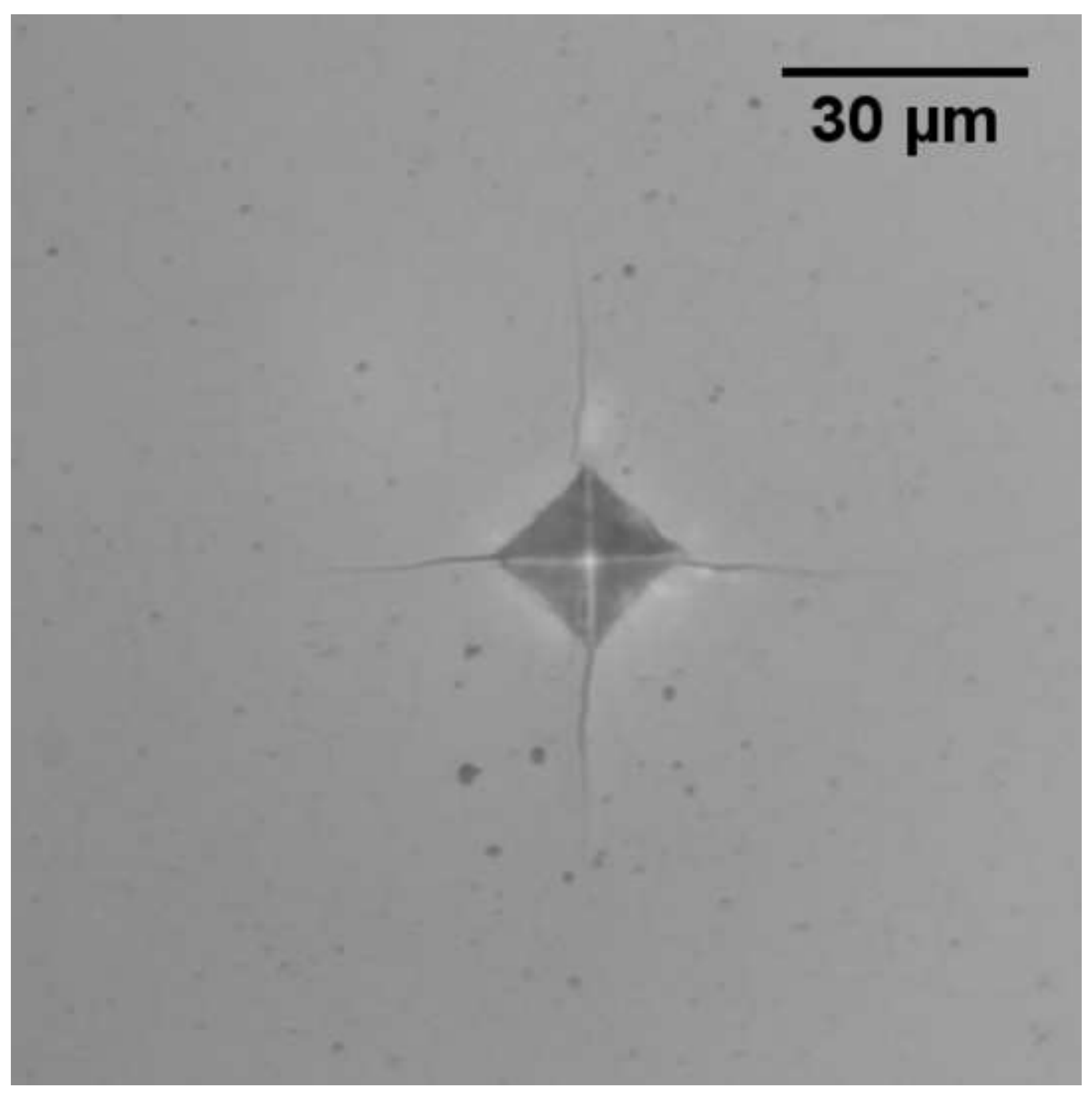

gure 2

.
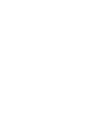

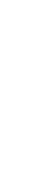

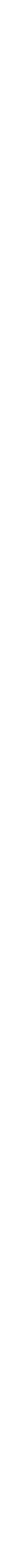

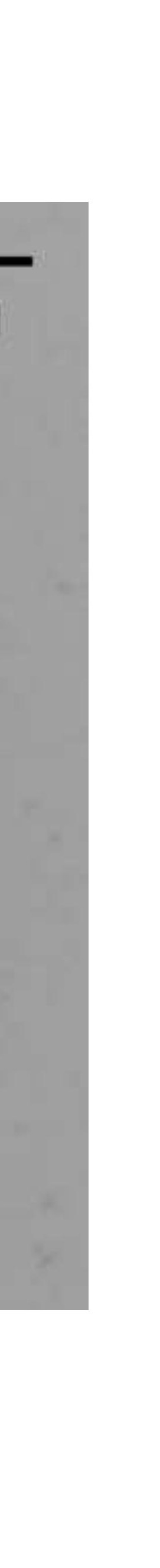

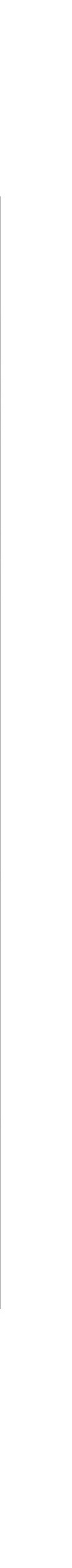

\section{$30 \mu \mathrm{m}$


Figure 3 a
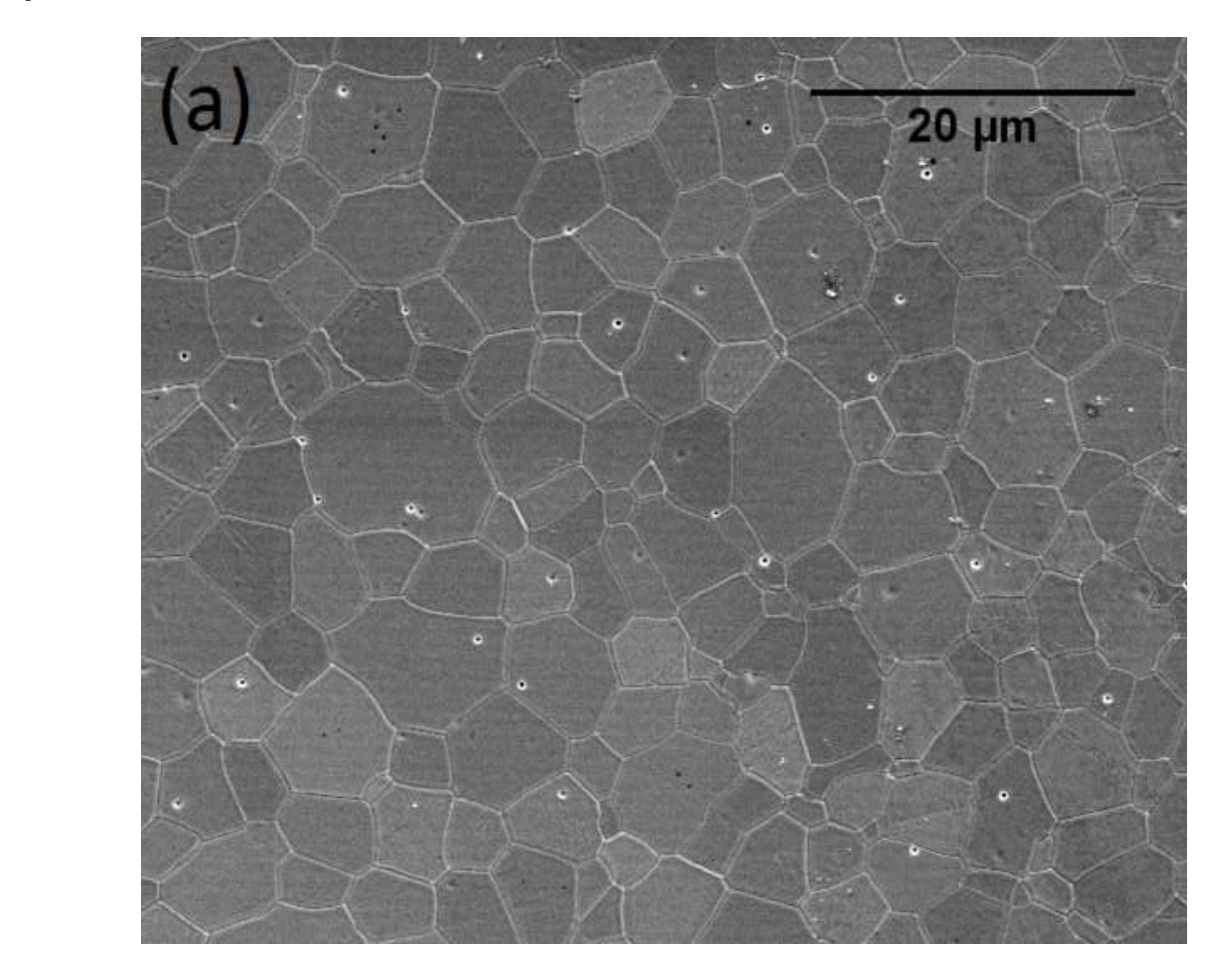

Figure
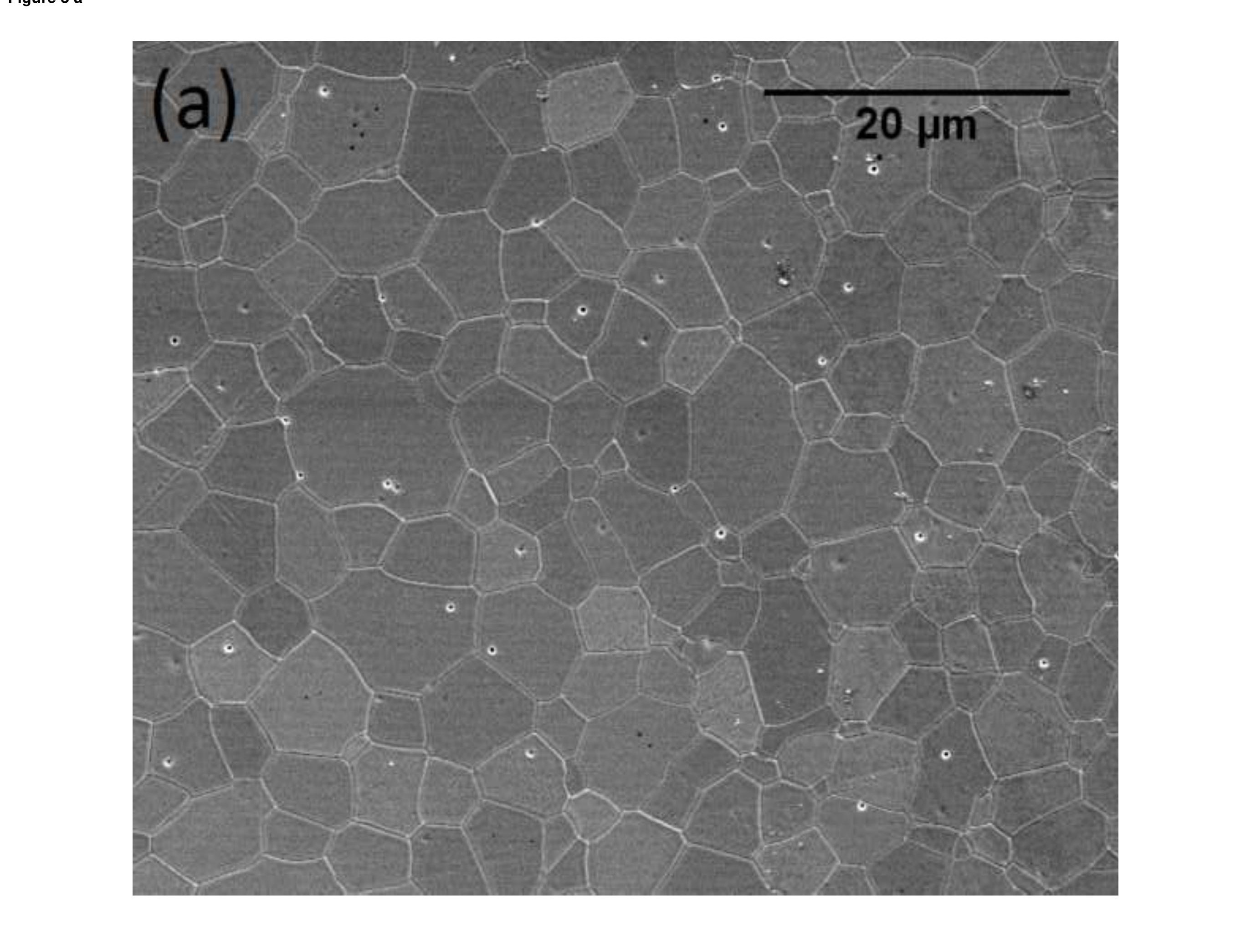


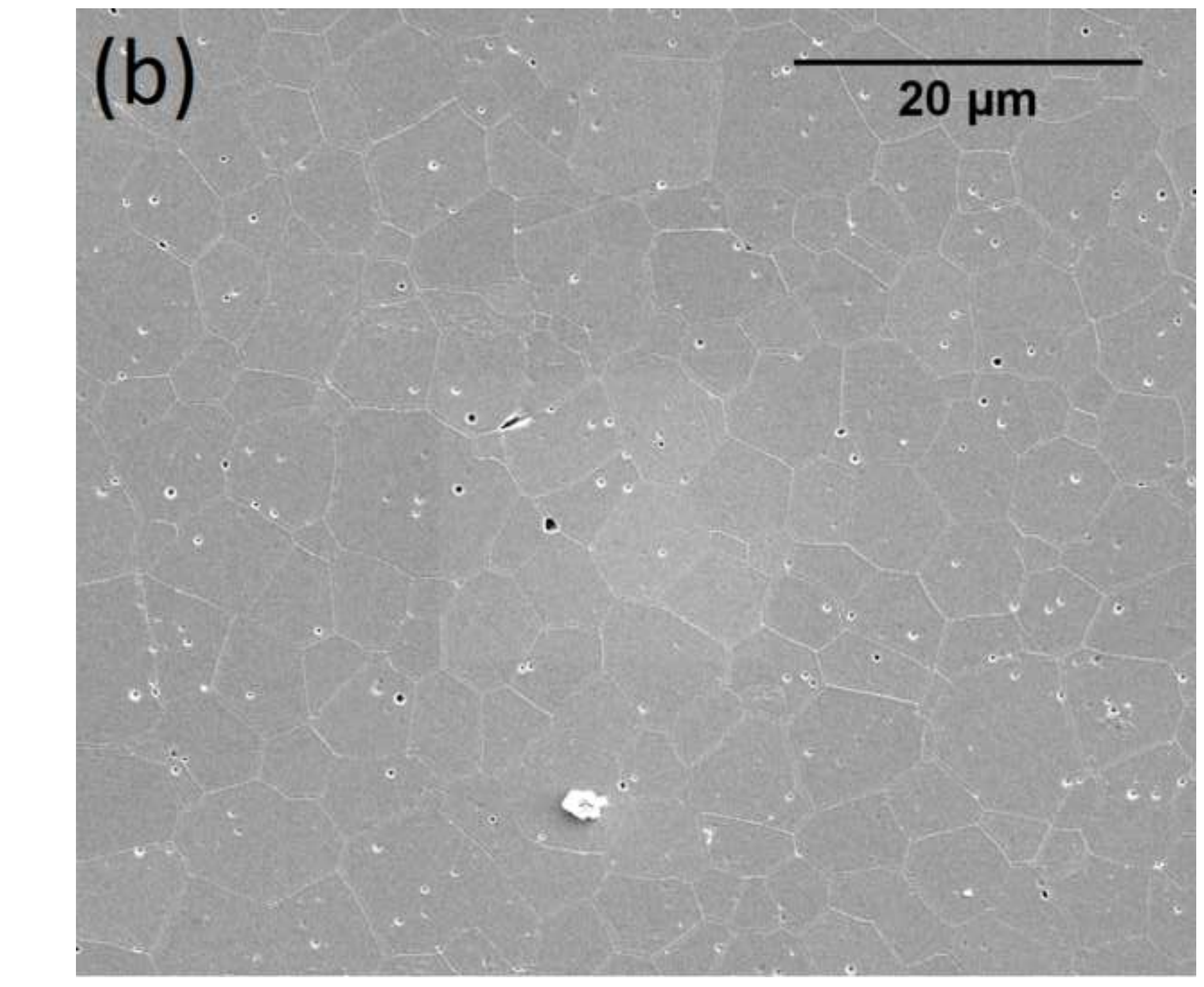

\section{Fure 3}

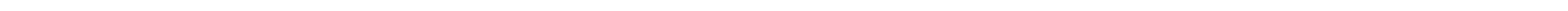


Figure $3 \mathrm{c}$
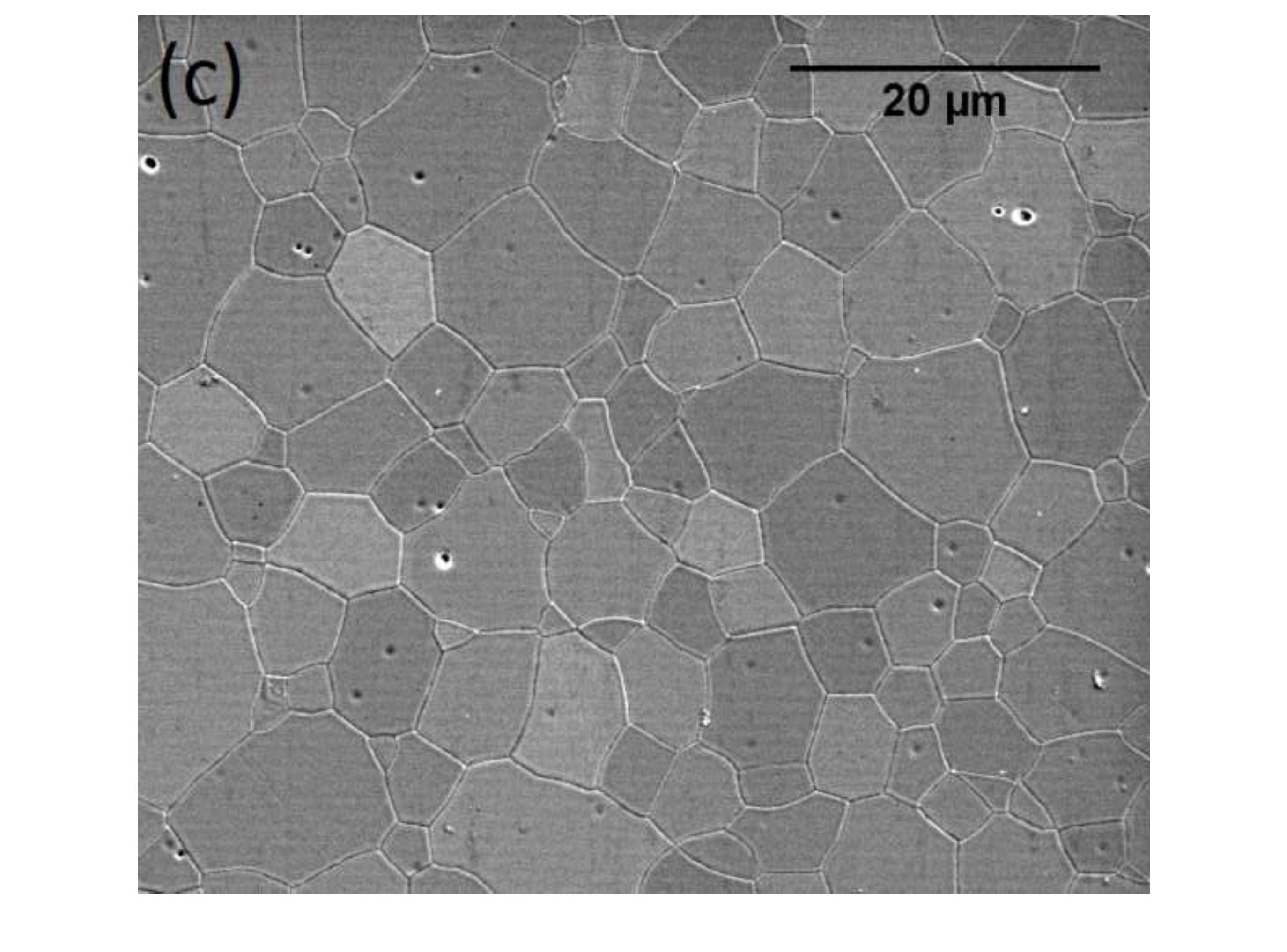

-
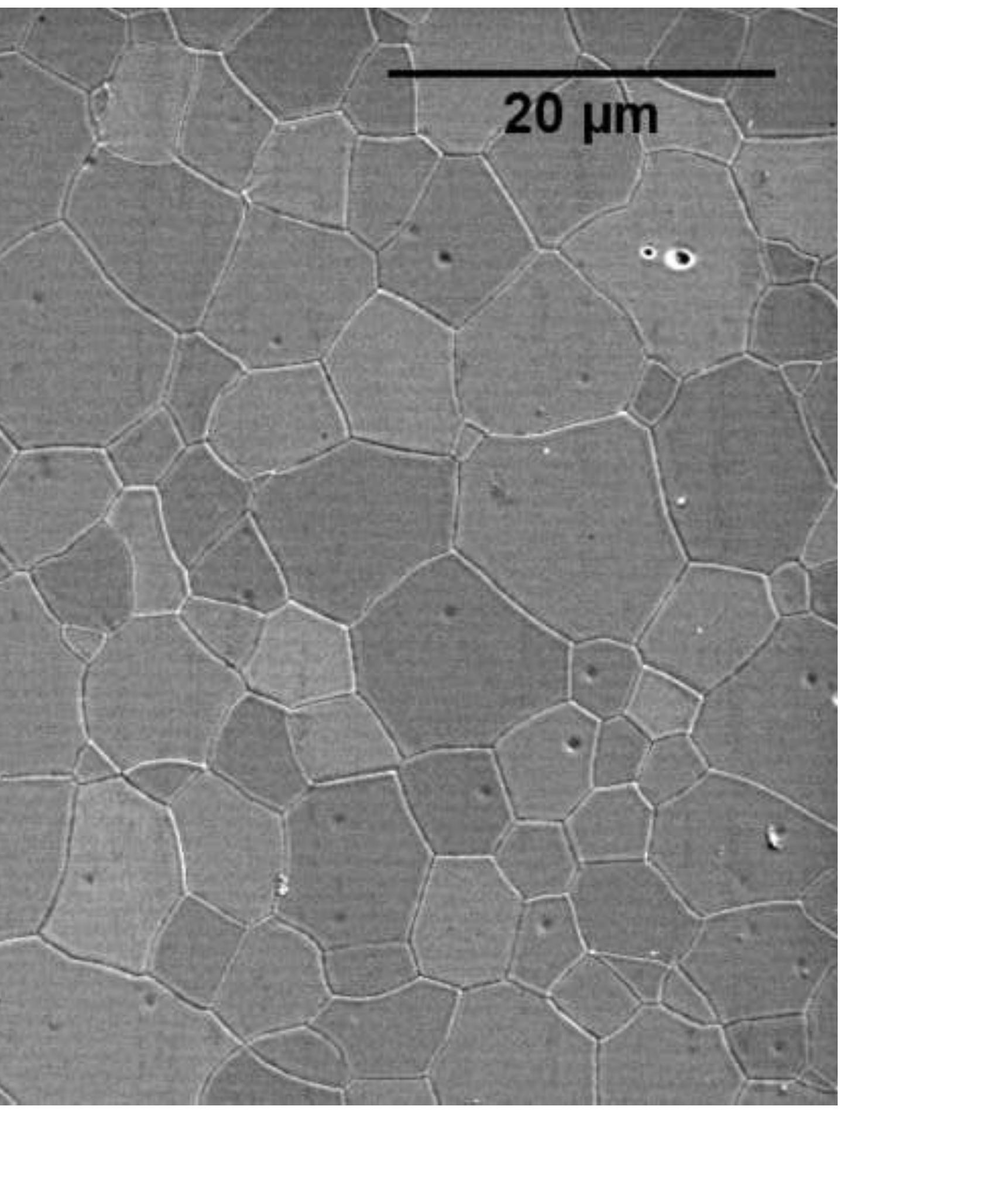
350

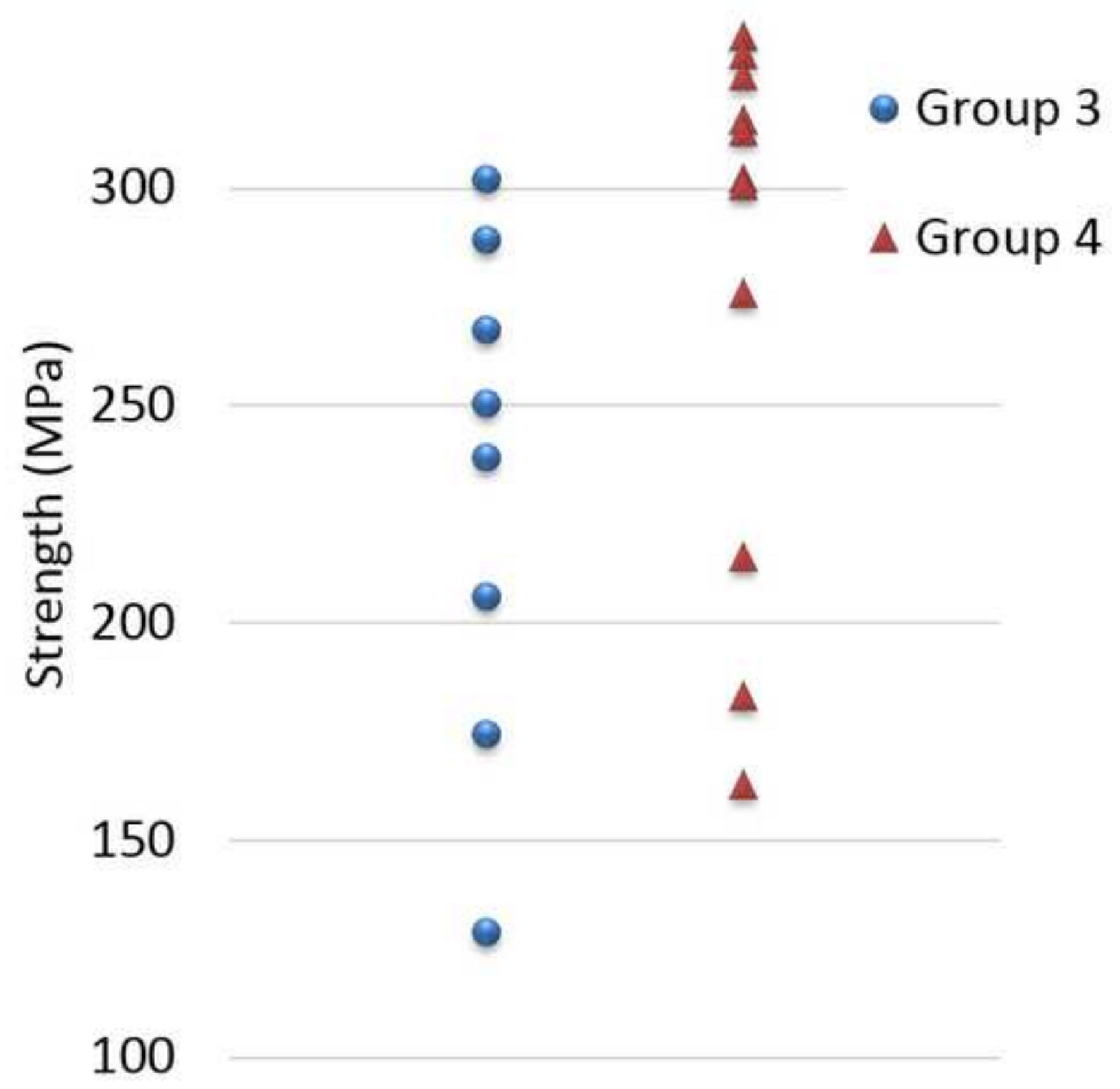

